\title{
Enterprise Risk Management (ERM), Corporate Governance Mechanism and Firm Value of the Financial Sector Company in Indonesia
}

\author{
Raudhatul Hidayah ${ }^{1}$, Abdul Rohman ${ }^{2}$, Agus Purwanto ${ }^{3}$, Bestari Dwi Handayanid ${ }^{4}$ \\ \{lovelyraudha@yahoo.com ${ }^{1}$ \} \\ Universitas Andalas, Indonesia ${ }^{1}$ \\ Universitas Diponegoro, Indonesia ${ }^{2,3}$ \\ Universitas Negeri Semarang, Indonesia ${ }^{4}$
}

\begin{abstract}
Firm value is the investor's perceptive of the company's success rate. Many factors affect the high value of the firm. This study aimed at examining the effect of Enterprise Risk Management (ERM) and corporate governance mechanisms on firm value. Research population consisted of financial sector companies listed on the Indonesia Stock Exchange, which were selected by a purposive sampling technique. This study performed an Ordinary Least Square (OLS) Regression analysis. The study proved significant effects of ERM and corporate governance mechanisms (managerial ownership, institutional ownership, independent commissioners and audit committees) on firm value.
\end{abstract}

Keywords: ERM, Corporate Governance Mechanism, Firm Value

\section{Introduction}

Firm is established to give maximum advantage and welfare to its stakeholders. Both aspects are made possible when the stock price is high and the firm puts its value highly.

According to Husnan [1], firm value is a value that potential buyers are willing to pay when the firm is sold. The firm value is an investor's perception of its degree of success. When stock price is high, so is the firm value. The high stock price will create trust on both firm's current and future performance.

Value of a firm can be built and sustained by a good corporate governance (GCG). Once the GCG is established, the firm is on the right track towards reducing risk of the future losses, which may affect its value.

This study applies four mechanisms to measure the GCG, i.e., managerial ownership, institutional ownership, independent commissioner, and audit committee. Managerial ownership help managers to be responsible for their firm because they are not only hired externalities, but also the ones who contribute to other stakeholders in the firm's decisionmaking process. This managerial ownership creates a work in concert between the managers and the stakeholders, in which both affects the management performance.

Institutional ownership helps improve the firm's monitoring on the insiders' performance [2]. Any action taken by the manager that may cause the firm's benefit can be reduced by the managerial ownership and institutional ownership, in which independent commissioner plays a significant part. Independent commissioner acts impartially in order to help create the GCG to avoid any possible fraud by the management in presenting the financial statement. 
Independent commissioner plays its role in monitoring the firm performance by establishing an audit committee. Once the audit committee has been put into action, an optimal performance will tend to materialize. The independent commissioner and the audit committee create transparency in the management responsibilities for the corporate financial statement.

Previous studies on the Corporate Governance have been done by Suyanti et al. [3], which results in the effect of the CG mechanism on the firm value, Rupilu [4], which indicates the significant effect of the $\mathrm{CG}$ on the firm value.

Furthermore, in a study of the effect of the CG and financial leverage on the firm value in the United States, Gill and Obradovich [5] finds that the effect is significant. Finally, having examined the effect the CG on the firm value, Perdana and Raharja [6] report as follows: a positive and significant effect of the managerial ownership on the firm value; a positive but not significant effect of the institutional ownership on the firm value; a positive and significant effect of the independent commissioner proportion on the firm value; and a positive but not significant effect of the external auditor on the firm value.

This current study has its own standing position by examining the effect of the CG on the firm value and the effect of the Enterprise Risk Management (ERM) on the firm value. The study uses different samples, i.e., firm that runs in financial sector.

Financial sectors play a significant role in stimulating economic growth of a country [7]. Globalization has been creating an integrated financial market that leads to vast growing external and internal environments of the financial sector. Banking industry has been popularly trusted as performing an intermediating function, in which it is expected to help minimize potential losses amid business risks.

Risk Management is an ultimate part of the banking industry in Indonesia in order to improve risk awareness. The Risk Management application within the banking industry relates to the increasing risks the bank must deal with. Effort in improving the risk management application is possible through integrated risk management by means of Enterprise Risk Management (ERM).

Bertinetti, Cavezzali and Gardenal [8] find that the ERM application has a positive and significant effect on the firm value, in which the ERM is considered more likely as a value driver, instead of a cost. The study supports the previous findings, which indicates a positive correlation between the firm value and the ERM and the empirical results that ERM helps improve the firm value [9].

\section{Hypotheses}

This study proposes the following hypothesis:

H1 : Managerial Ownership has a significant effect on Firm Value

$\mathrm{H} 2$ : Institutional Ownership has a significant effect on Firm Value

H3 : Independent Commissioner has a significant effect on Firm Value

H4 : Audit Committee has a significant effect on Firm Value

H5 : Enterprise Risk Management (ERM) has a significant effect on Firm Value 


\section{Method}

Population of this study consisted of banking firms enlisted in the 2017-2019 Indonesia Stock Exchange, which were collected by a purposive sampling technique [10].

Three criteria applied to the sampling mechanism, as follows: 1) the ISX-listed banking forms had to publish annual report for the period ended on December 31st for three consecutive years (2017-2019); 2) the firms disclosed the ERM and informed their value; and 3) the firms had complete and clear data within their annual financial statement during the research observation. These criteria resulted in 75 firms eligible for the research samples.

Table 1. Research Variable Measurement

\begin{tabular}{|c|c|c|c|}
\hline Variabel Name & Abbreviation & Variable & Measurement \\
\hline $\begin{array}{l}\text { Managerial } \\
\text { Ownership }\end{array}$ & KEM & Exogenous & $\frac{\text { Number of shares owned by manager x } 100 \%}{\text { Number of shares in operation }}$ \\
\hline $\begin{array}{l}\text { Institutional } \\
\text { Ownership }\end{array}$ & KEI & Exogenous & $\frac{\text { Number of shares owned by institution } \mathrm{x} 100 \%}{\text { Number of shares in operation }}$ \\
\hline $\begin{array}{l}\text { Independent } \\
\text { Commissioner }\end{array}$ & KOI & Exogenous & $\frac{\text { Number of independent commissioner } \times 100 \%}{\text { Number of boards of commissioner members }}$ \\
\hline $\begin{array}{c}\text { Audit } \\
\text { Committee }\end{array}$ & KA & Exogenous & $\frac{\text { Number of independent commissioner x } 100 \%}{\text { Number of boards of commissioner members }}$ \\
\hline Firm Value & $E R M$ & Exogenous & $\begin{array}{l}\text { ERM consisted of } 127 \text { according to the } \\
\text { Appendix of the Central Bank Circular Letter } \\
\text { No.13/23/DPNP dated October } 25^{\text {th }}, 2011 \text {, on } \\
\text { the Application of Risk Management for } \\
\text { Commercial Bank. } \\
\text { Tobin's Q = (MVS + MVD)/RVA }\end{array}$ \\
\hline
\end{tabular}

This study used secondary data from audited financial statement and annual report already listed in the 2017-2019 ISX. The study analyzed these data by using Ordinary Least Square (OLS) Multiple Regression operated by the Statistical Product and Service Solutions (SPSS) Version 24.

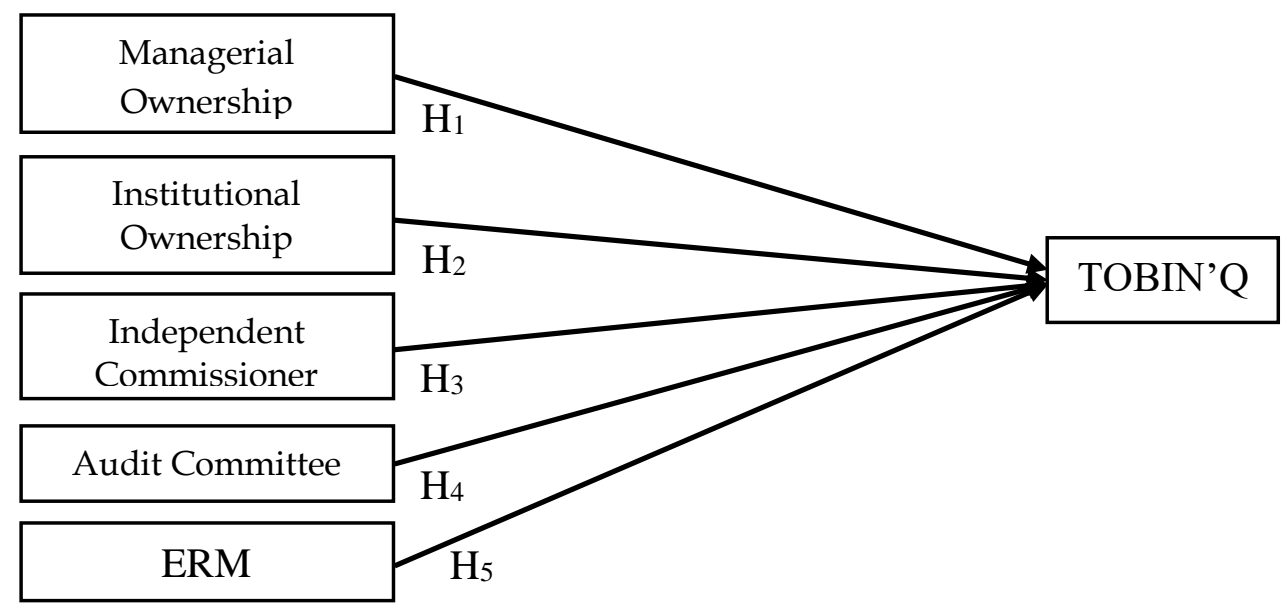

Fig. 1. Research Model. 


\section{Results}

Regression analysis applied to examine the effect of exogenous variables on the endogenous ones.

This study applied a multiple regression to find out the exogenous variables, i.e., CG and ERM, and the endogenous variable, i.e., Firm Value.

Results of the regression are as the followings:

Table 2. Results of Regression Coefficient

\begin{tabular}{ccccccc}
\hline \multirow{2}{*}{ Model } & \multicolumn{2}{c}{$\begin{array}{c}\text { Unstandardized } \\
\text { Coefficient }\end{array}$} & $\begin{array}{c}\text { Standardized } \\
\text { Coefficient }\end{array}$ & & Sig \\
\cline { 3 - 5 } & & B & Std. Error & Beta & & t \\
\hline 1 & (Constant) & 1,873 & 0,587 & & 2,798 & 0,002 \\
& ERM & 0,438 & 0,082 & 0,109 & 3,503 & 0,000 \\
& KEM & 1,086 & 0,209 & 0,310 & 4,965 & 0,001 \\
& KEI & 0,531 & 0,074 & 0,172 & 3,207 & 0,000 \\
& KOI & 1,639 & 0,310 & 0,351 & 5,102 & 0,000 \\
& KOA & 0,784 & 0,096 & 0,164 & 3,097 & 0,003 \\
\hline
\end{tabular}

The above regression output resulted in the following regression equation:

Tobin' $\mathrm{Q}=1,873+$ 0,438 ERMit + 1,086 KEMit + 0,531 KEIit $+1,639$ KOIit $+0,784$ 0,784 $=0,784$

\subsection{Determination and Correlation Coefficients}

The regression test resulted in the following determination and correlation coefficients:

Table 3. Results of Determination and Correlation Coefficients

\begin{tabular}{ccccc}
\hline Model & R & R. Square & Adjusted R. Square & Std. Error of the Estimate \\
\hline 1 & 0,530 & 0,291 & 0,273 & 0,60127 \\
\hline
\end{tabular}

\subsection{Hypothetical Test}

The research hypotheses were subject to partial test (t-test) as presented in the following table 4.

Table 4. Results of t-test coefficient

\begin{tabular}{ccccccc}
\hline \multirow{2}{*}{ Model } & \multicolumn{2}{c}{$\begin{array}{c}\text { Unstandardized } \\
\text { Coefficient }\end{array}$} & $\begin{array}{c}\text { Standardized } \\
\text { Coefficient }\end{array}$ & & \\
\cline { 3 - 5 } & & B & Std. Error & Beta & t & Sig \\
\hline \multirow{2}{*}{1} & (Constant) & 1,873 & 0,587 & & 2,798 & 0,002 \\
& ERM & 0,438 & 0,082 & 0,109 & 3,503 & 0,000 \\
& KEM & 1,086 & 0,209 & 0,310 & 4,965 & 0,001 \\
& KEI & 0,531 & 0,074 & 0,172 & 3,207 & 0,000 \\
& KOI & 1,639 & 0,310 & 0,351 & 5,102 & 0,000 \\
& KOA & 0,784 & 0,096 & 0,164 & 3,097 & 0,003 \\
\hline
\end{tabular}


The above table indicates that $t$-test on the ERM variable on the firm value was 3.503 with significance rate of 0.000 . This rate was less than $5 \%$, therefore H0 was unacceptable. In conclusion, the ERM had a positive and significant effect on the firm value.

The t-test resulted 4.965 rate for managerial ownership with significance rate of 0.001 , indicating a positive and significant effect of the managerial ownership on the firm value, and 3.207 rate for institutional ownership with significance rate of 0.000 , indicating a positive and significant effect of the institutional ownership on the firm value.

Furthermore, the t-test resulted in 5.102 rate for independent commissioner with significance rate of 0.000 , indicating a positive and significant effect of the independent commissioner on the firm value, and 3.097 rate for audit committee with significance rate of 0.003 , indicating a positive and significant effect of the audit committee on the firm value.

\section{Discussion}

\subsection{Effect of Managerial Ownership on Firm Value}

Manager is responsible for firm sustainability. Managerial ownership makes possible for the manager to express his or her sense-of-belonging in performing the firm management. The managerial ownership puts management's interest and stakeholder's interest at the same level, so there is going to be a mutual responsibility should there be any incorrect decision-making $[3]$.

Research observation found that managerial ownership had a significant effect on the firm value, in line with agency theory, which states that managerial ownership is an effective mechanism to resolve agency conflicts of interest between the principal (owner) and the agent (manager). The results support the previous studies that managerial ownership has a significant effect on the firm value [11][6][12].

\subsection{Effect of Institutional Ownership on Firm Value}

Institutional ownership is capable of performing an effective monitoring mechanism for each decision made by the manager [13]. The higher the institutional ownership rate, the stronger monitoring the institutional investors have to avoid the manager's opportunistic behaviors [14].

Test on the effect of the institutional ownership on the firm value in this study had a significant result, in line with the agency theory, which states that institutional ownership plays a very important role in minimizing agency conflicts. The agency conflicts cause agency cost. The higher rate of institutional ownership leads to the stronger control of the externalities over the firm, so that the agency cost can be reduced while increasing the firm value [4].

The current study agrees with one that of Suyanti et al. [3] in terms that institutional ownership has a positive effect on firm value. However, it does not accord with another study performed by Perdana and Raharja [6], which finds no significant effect of the institutional ownership on the firm value.

\subsection{Effect of Independent Commissioner on Firm Value}

Independent commissioner is the most appropriate position for performing a monitoring function towards a good corporate governance [3]. The higher the proportion of the independent commissioner within the firm, the more empowered the board of commissioner in performing 
its effective and efficient monitoring and advocacy functions for the board of directors to contribute the added value to the firm.

The test on the effect of the independent commissioner on the firm value in this study is in line with that of Perdana and Raharja [6] in terms of the positive and significant effect of the independent commissioner on the firm value. However, the result goes to the opposite direction from Nathania [15] who has proven that the independent commissioner had a negative and not significant effect on the firm value.

\subsection{Effect of Audit Committee on Firm Value}

Audit committee is useful for improving integrity and credibility of financial statement. An independent audit committee helps control the transparency of the firm management reporting, leading to trust and belief from stock market actors.

This study indicated that audit committee was one of indicators that affected firm value, supporting the agency theory, which predicts that the establishment of the audit committee helps agency problem-solving mechanism. The audit committee plays its role as a controller in the financial statement development. Therefore, it affects the increase in the firm value.

On one hand, this study agreed with the previous findings that audit committee had a significant effect on the firm value [5][4]. On the other hand, it was against Suyanti et al. [3], Felmania [11], and Perdana and Raharja [6], who found a non-significant effect of the audit committee on the firm value.

\subsection{Effect of ERM on Firm Value}

As a non-financial information, ERM becomes a signal for investors concerning their invested capital security. The better and the clearer ERM presentation within the firm's report, the stronger the motivation of the investors to make the investments. The quality of the ERM also motivates the investors to get the firm's certificate of the property rights and to make a competitive price on the stock market.

The test on the ERM's effect on the firm value accorded with Hoyt and Liebenberg [9] in terms of the significant effect the ERM had on the firm value, but did not agree with Tahir and Razali [16] and Sekerci [17] who found non-significant effect of the ERM on the firm value.

\section{Conclusion}

This study examined the effects of the corporate governance mechanisms and the ERM on the firm value, which resulted that the firm value of the research samples, i.e., financial sector companies listed in the 2017-2019 ISX, were affected by the corporate governance mechanisms (managerial ownership, institutional ownership, independent commissioner, and audit commissioner) and the ERM. The contribution of this study made both theoretical and empirical contributions. The theoretical realm supported the agency theory, whereas the empirical realm supported the effect of the CG mechanisms and the ERM on the firm value. 


\section{Recommendations}

This study gives direction of how firm management acknowledges the correlation of the CG mechanisms and the ERM to the firm value. It warns the management to pay attention to CG mechanisms by examining managerial ownership and institutional ownership composition, as well as finding out whether independent commissioner and audit committee exist within the firm. A firm must have well-planned consideration to minimize agency cost while increasing its value.

Firms are necessary to increase the frequency of the ERM disclosure to prove that they have been "prepared for the worst" (i.e., failure risk) and for minimizing the loss. Once the loss has been overcome, the firms are not going to bother themselves by manipulating the financial statement, creating a stronger investors' trust and a higher firm value.

In terms of science and knowledge development, this study expands the empirical evidence on the firm value, opening doors for further research on other factors, either those strengthening or weakening, the firm value. Further research may include dividend policy, corporate social Responsibility, financial performance ratio, and investment opportunity set.

The study also recommends a further research on the ERM based on other aspects than implementation items. It recommends Likert scale that inclines more to the smaller intervals. The research observation period must also expand beyond three-year term to enrich the data for the sake of a better decision-making.

\section{References}

[1] S. Husnan, "Manajemen Keuangan Teori dan Penerapan (keputusan jangka panjang)," Yogyakarta BPFE, vol. 12, p. 40806, 2000.

[2] F. Navissi and V. Naiker, "Institutional ownership and corporate value," Manag. Financ., 2006.

[3] A. N. Suyanti and Y. A. Aryani, "Pengaruh Mekanisme Corporate Governance Terhadap Nilai Perusahaan Dengan Kualitas Laba Sebagai Variabel Intervening Pada Perusahaan Manufaktur Yang Terdaftar Di Bursa Efek Indonesia Periode 2004-2007,” J. Ekon. BISNIS, p. 173, 2010.

[4] W. Rupilu, "Pengaruh mekanisme corporate governance terhadap kualitas laba dan nilai perusahaan pada perusahaan manufaktur yang terdaftar di Bursa Efek Indonesia," J. Akuntansi, Manaj. Bisnis dan Sekt. Publik, vol. 8, no. 1, pp. 101-127, 2011.

[5] J. Obradovich and A. Gill, "The impact of corporate governance and financial leverage on the value of American firms," 2013.

[6] R. S. Perdana and R. Rahardja, "Analisis pengaruh corporate governance terhadap nilai perusahaan,” Diponegoro J. Account., pp. 766-778, 2014.

[7] I. Inggrid, "Sektor Keuangan dan Pertumbuhan Ekonomi di Indonesia: Pendekatan Kausalitas dalam Multivariate Vector Error Correction Model (VECM)," J. Manaj. dan Kewirausahaan, vol. 8 , no. 1 , pp. 40-50, 2006

[8] G. S. Bertinetti, E. Cavezzali, and G. Gardenal, "The effect of the enterprise risk management implementation on the firm value of European companies," Dep. Manag. Univ. Ca'Foscari Venezia Work. Pap., no. 10, 2013.

[9] R. E. Hoyt and A. P. Liebenberg, "The value of enterprise risk management," J. Risk Insur., vol. 78, no. 4, pp. 795-822, 2011.

[10] Sugiyono, Metode Penelitian Pendidikan. Bandung: Alfabeta, 2013.

[11] M. Felmania, "Good corporate governance mechanism, corporate social responsibility disclosure on firm value: empirical study on listed company in indonesia stock exchange," Int. J. Financ. Account. Stud., vol. 2, no. 1, pp. 1-10, 2014.

[12] I. Iswajuni, S. Soetedjo, and A. Manasikana, "Pengaruh Enterprise Risk Management (Erm) Terhadap Nilai Perusahaan Pada Perusahaan Manufaktur Yang Terdaftar Di Bursa Efek,” J. Appl. 
Manag. Account., vol. 2, no. 2, pp. 275-281, 2018.

[13] D. Sukirni, "Kepemilikan manajerial, kepemilikan institusional, kebijakan deviden dan kebijakan hutang analisis terhadap nilai perusahaan," Account. Anal. J., vol. 1, no. 2, 2012.

[14] Y. A. Wiranata and Y. W. Nugrahanti, "Pengaruh struktur kepemilikan terhadap profitabilitas perusahaan manufaktur di Indonesia," J. Akunt. dan Keuang., vol. 15, no. 1, pp. 15-26, 2013.

[15] A. Nathania, "Pengaruh komposisi dewan perusahaan terhadap profitabilitas perusahaan," Finesta, vol. 2, no. 1, pp. 76-81, 2014.

[16] I. M. Tahir and A. R. Razali, "The relationship between enterprise risk management (ERM) and firm value: Evidence from Malaysian public listed companies," Int. J. Econ. Manag. Sci., vol. 1, no. 2, pp. 32-41, 2011.

[17] N. Sekerci, "Does Enterprise Risk Management create value for firms?: Evidence from nordic countries," in 7th Nordic Econometric Meeting 2013 in Bergen, 2013, pp. 1-43. 